\title{
研究者のふれあいの場 Microlab
}

Microlab Provides Us the Human Network

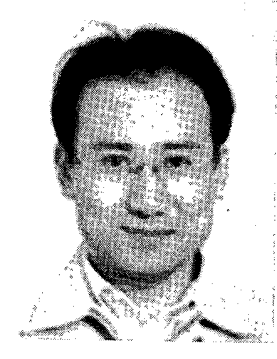

坂上 英一

Eiichi Sakaue

1967年5月生まれ

1990年早稲田大学理工学部応用物理学科卒業

1992年早稲田大学大学院修士課程修了

四主として行っている業務・研究

・マイクロマシンの研究

且所属学会および主な活動

日本機械学会, IEEE (The Institute of Electrical and

Electronics Engineering)

四勤務先

（株）東芝 研究開発センター 機械・システムラボラトリー 研究主務

( ₹212-8582 川崎市幸区小向東芝町／

E-mail : eiichi.sakaue@toshiba.co.jp)
“Microlab". カリフォルニア大学 バークレ一校の半導体プロセス関係の 実験室の名称だ．そこは筆者にとって いろいろな人間とふれあえる貴重な場 だった. 日本にもっとこのような場所 ができればと願い，この場を借りて紹 介する。

筆者は同校の電気工学部のConnie Chang-Hasnain教授の研究室で 2000年8月から 1 年半, 企業派遣研 修生 “Visiting Industrial Fellow" として過ごした，単位は取れないが授 業も聴講し，宿題も解き，ほぼ学生と 同じような生活を送った。

同教授は, 面発光レーザの一方の共 振ミラーをMEMS (Micro Electro Mechanical Systems) でモノリシ カルに作成したカンチレバーの先に載 せた波長チューナブルレーザを作成し た. 静電引力でレバーをアクチュエー トすることで共振長を制御する，筆者 はその技術を応用し，レーザとアクチ ユエータブルな光導波路とをMEMS でモノリシックに作り，レーザ光を高 速に走査するデバイスを作成し，動作 させることができた，試行錯誤を繰り 返し，連日Microlabに閉じこもって デバイスを作成した，大学まで片道 $6 \mathrm{~km}$ (途中に急坂2箇所あり) を目転
車で通っていたが，幸か不幸か夜10 時に女の子が犬と散歩している程, 治 安に問題がなかったので, 夜12時を 超えて帰宅しても問題なかった（逆に 周囲に怪しまれた)。

Microlabの運営システムは合理的 である．学内にありながら月会費を支 払えば一般企業でも利用が可能で，大 学からある意味独立している，学生が 利用しても担当教授に請求がいく. 教 授の懐が寂しくなると，研究室の学生 も実験ができない，利用メンバーにな るにはお金を払う以外に，薬品の取扱 い方, 緊急時の対応の仕方等, 安全に

\section{図1 大学の風景}

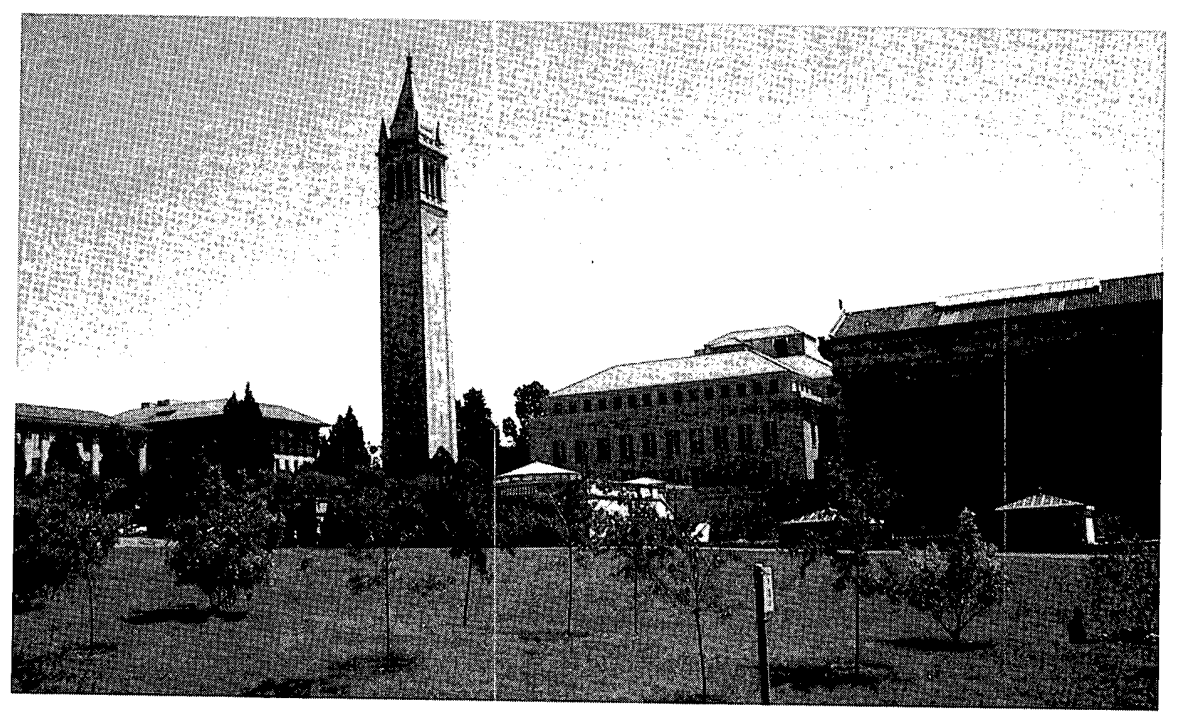

関するペーパー試験をパスしなければ ならない，「薬品を浴びた場合どのよ うな対処を採るか」の類の設問で，フ ッ化水素を「HF」と書いてくれれば よいが「Hydrogen Fluoride」とい う調子なので，解読に苦労した，また 個々の装置を使うごとに使用料が加算 される.すべての装置の脇に端末があ り，吅とパスワードを入力すると使え るようになる. 同時に課金もされる. ただ各装置のアクセス権を得ないと 各装置のスーパーユーザを適当につか まえて，模擬運転をみてもらい，合格 ID, パスワードを入力しても動かない. 
図 2 大学のある建物の最上階からの眺め（サンフランシスコ湾が見える）

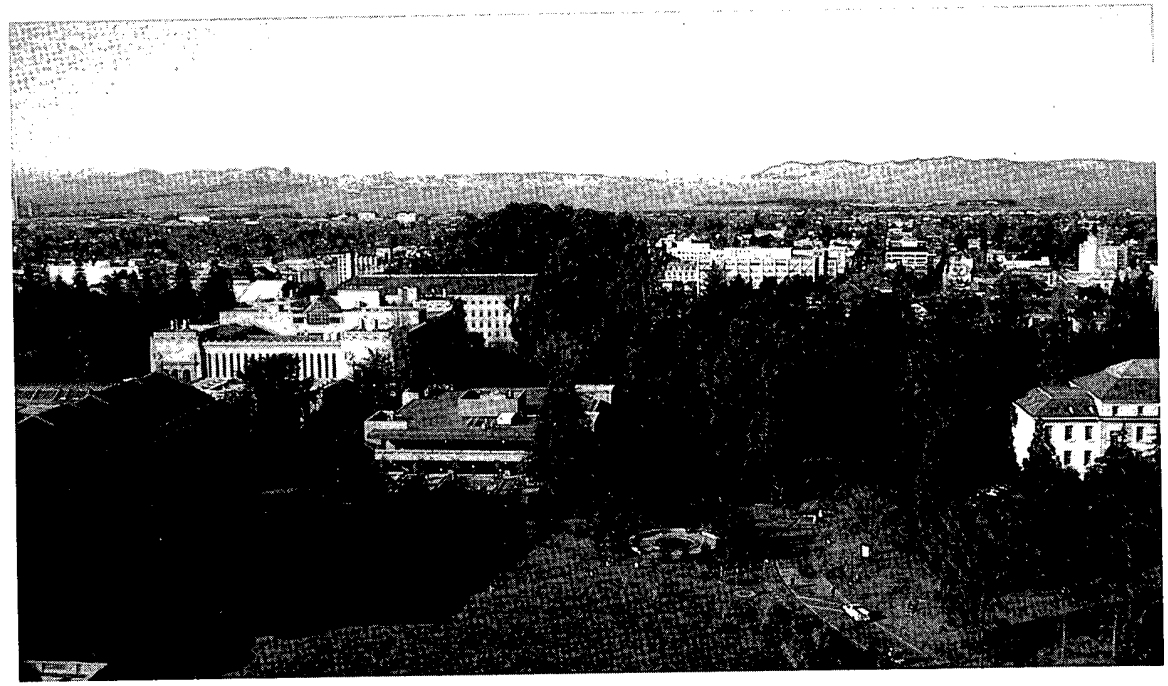

図 3 Microlabでの筆者

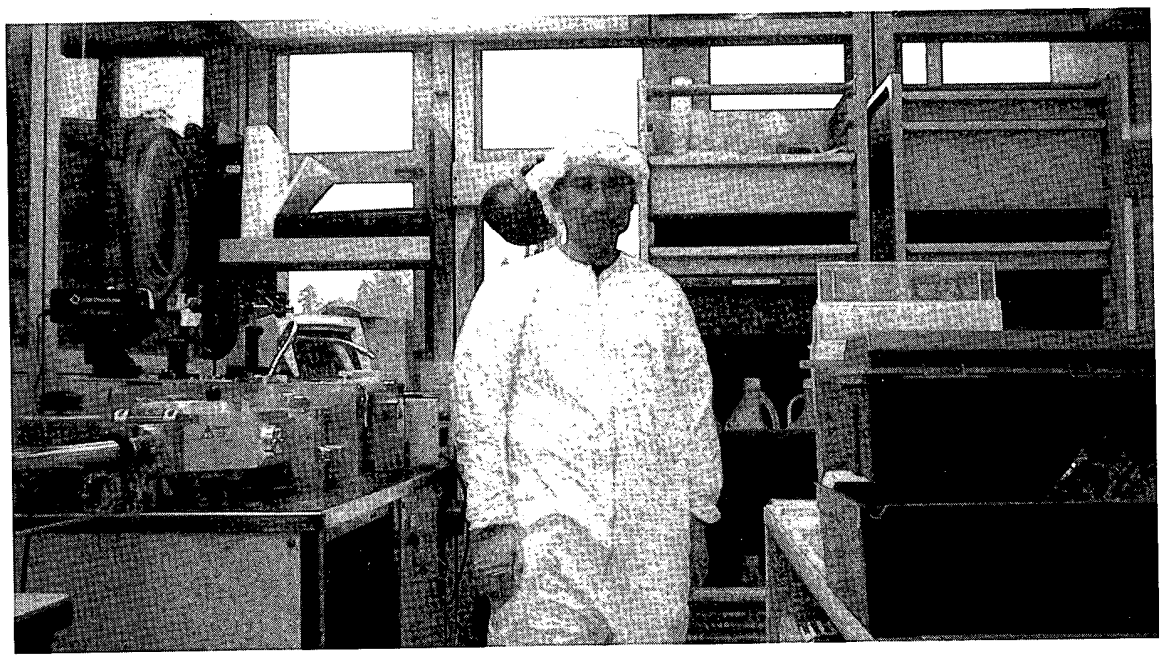

すれば所定用紙にサインをもらえる これをMicrolabの事務所に提出すれ ば晴れてアクセス権がもらえる．英語 で書かれた装置マニュアルを読んで覚 えるのも大変で, 結局MEMSプロセ スの全工程に必要な装置の権限を取得 するのにつ箇月程かかった。ただ，あ る装置が使えなくても， Micorlabのス タッフに人件費を払い，プロセスを肩 代わりしてもらうこともできる.イン ターネットで各装置の利用予約もでき る. 自分がいくら使ったかも端末から 一目で分かるので, コス卜意識もつく.

さまざまな人が使っているため装置 がよく故障する. 特に学会発表原稿締 切り間際によく起こる。修理はMicrolabのスタッフに頼む，大抵スタッフ は既に他の装置の故障を直しているこ とが多い，スタッフと日頃仲が良いと 「学会発表近いので先にこれ直して」 と泣きつける.人間関係がたいせつと
いうのは世界共通だと感じた。

外部にも貸出していることは，大学 にとって金銭的負担が小さいという以 外にもメリットがある。一つ小さい ベンチャー企業も高い装置を自前で持 たずに済むという点である。一種のイ ンキュベータの役割も持つ. 卒業生が 起業したり，社內プロジェクトを起こ したりして，実験に戻ってくるケース も多かった.二つ目は学生にとっても， 企業の人間と触れ合うことができるの で，一種の刺激になる点である，狭い 空間で実験をしていると，なんとなく お互い会話をする.おかげで多くの人 と知り合い，またさまざまな場面に出 会えた. ある日知人がうかない顔をし ていた．聞けば「勤務先から来月解雇 の通知を受けたよ」という（彼は努力 して大学院に入り直し, 今も研究を続 けている)。また評価装置の空待ちを している時, 前のユーザが筆者にデバ
イスを見せて「今，このデバイスで世 界最高の性能が出たよ」と嬉しそうに 語つたこともあつた.

ベンチャー企業の人間はよく働いて いたが，悲壮感はなく，明るく楽しそ うだった．やはり自分の成果がダイレ クトに会社の業績につながる責任感 と、ストックオプションという見返り が彼らをそうさせていると多くの人が いつていた。

蒸着装置を真空に引いている間な ど,ちょつとした時間手が離せる時は， 近くの力フェで仲間と雑談しながらコ ーヒーを飲んだり，テニスをしたりし た. 隣町オークランドに大リーグの試 合を見に行くために，この休鄎時間が 試合時間にくるようにプロセスを調節 したこともあった．

最後に，Microlabのスタッフの 方々と共同研究者のPaul君には本当 にお世話になった，感謝している。 